\title{
Crafting Preliminary Model for Mosque Cooperatives' Antecedents of Performance
}

\author{
Abdullah Sallehhuddin ${ }^{1}$, Al Mansor Abu Said ${ }^{2}$, Nor Hasmanto ${ }^{1}$, Mohd Ariff Mustafa ${ }^{2}$, Mohammad Jais ${ }^{2}$, Azizi \\ Samsudin $^{2}$, Md Shukor Masuod ${ }^{2} \&$ Hishamuddin Ismail $^{2}$ \\ ${ }^{1}$ Faculty of Management, Multimedia University, Cyberjaya, Malaysia \\ ${ }^{2}$ Faculty of Business, Multimedia University, Melaka, Malaysia \\ Correspondence: Mohd Ariff Mustafa, Faculty of Business, Multimedia University, Jalan Ayer Keroh Lama, \\ 75450, Melaka, Malaysia. Tel: 606-252-3822. E-mail: ariff.mustafa@mmu.edu.my
}

Received: November 24, 2016

doi:10.5539/ass.v13n2p116

\author{
Accepted: December 26, 2016 \\ Online Published: January 19, 2017 \\ URL: http://dx.doi.org/10.5539/ass.v13n2p116
}

The project is funded by Fundamental Research Grant Scheme (FRGS) and Fisabilillah Research Development Grant Scheme (FRDGS)

\begin{abstract}
This paper explored the determinants of performance of mosque cooperatives in Malaysia. Questionnaires were distributed among mosque co-operators in the state of Selangor, Negeri Sembilan, and Kuala Lumpur. Forty-one questionnaires were returned and found fit for further analysis using Partial Least Square (PLS) method. The findings postulated three determinants of mosque cooperatives' performance viz. board members' characteristic, internal supervision and monitoring, and members' support. The antecedents of mosque cooperative performance initial model also met the requirement for convergence validity, discriminant validity, and reliability. The PLS result showed that board members' characteristics, members' support, and internal supervision and monitoring positively determined mosque cooperatives' financial performance, and eventually financial performance influenced non-financial performance. The findings are expected to benefit regulator, national apex cooperative (ANGKASA), and mosque co-operators in illustrating an appropriate mechanism to boost performance in coming years.
\end{abstract}

Keywords: Cooperatives, Mosque, Mosque Cooperatives and Performance

\section{Introduction}

In achieving the full potential, mosque co-operatives need to show a good performance, financially and non-financially. Without strong financial support, it is difficult for mosque cooperatives to score in non-financial aspects. Mosque cooperatives performances are still held up by multiple challenges such as management weaknesses, inexperienced talents, inadequate resources, and poor internal governance. In fact, according to Suruhanjaya Koperasi Malaysia (SKM) - a regulator, as at June 2015, only 141 of 286 registered mosque cooperatives documented profits (SKM, 2015). Hence, the understanding of mosque cooperatives' performance is crucial. On the other hand, existing studies were heavily focusing performance of conventional cooperatives such as school cooperatives, and other types of community based cooperatives, even though SKM, ANGKASA, and National Cooperative Policy 2/DKN 2, $2011-2020$ have emphasised special efforts on mosque cooperatives (SKM, 2011). Besides, multiple available studies have formulated frameworks to measure cooperatives' performance; yet the models are a lack of validation or financially performance drove investigation, and resulted in inconsistent findings. Hence, this study aims to bear out the gap by proposing initial integrated and validated model of antecedents of mosque cooperative financial and non-financial performance.

\section{Literature Review and Hypothesis Formulation}

\subsection{Performance of Mosque Cooperatives}

In this sub-section, several past studies were evaluated and examined concerning the performance of cooperatives. The performances were divided into two aspects namely financial performance and non-financial performance. 


\subsubsection{Financial Performance}

All types of organisations require performance management. These include profit oriented entities, non-profitable organisations; even to entities that have two equally important objectives such as cooperative. Cooperative carries out business activities to generate revenues and profits, which then will be used to support its members' social needs. Performance measurement is crucial to provide information to board directors and management teams on cooperative's abilities to fulfill both economic and social goals. The performance measurement data leads to a better strategic management among cooperative. Besides, corrective actions could be designed to fix the identified weaknesses.

The general "objective of a co-operative is to maximise the benefits to its members and ensure that their needs are met" (Sushila, Noordin, Said, Juhan, \& Mohd Hanif, 2009). Despite such objective, co-operative faces challenge in the dynamic business world. Like other business entities, the cooperative needs to generate more revenues, manages costs, and records profit. Subsequently, enables cooperative to support its social objectives towards members and society. Besides, cooperative's board members and management team must manage risks, oversee cash flow, utilise and optimise assets, and administer short-term or long-term obligations. Therefore, according to Kaur (2006), cooperative's financial performance is widely measured by adopting a common accounting and finance ratios such as profitability, liquidity, efficiency, and leverage. The similar stance was also supported by Chesnick (2005); Hind (1999); Sushila, Noordin, Said, Juhan, \& Mohd Hanif (2010).

Hence, from mosque cooperative perspective, being a business entity, it has to show strong financial performance. A strong financial performance enables mosque cooperative to provide benefits and supports towards members or community in a sustainable manner. Thus, traditional accounting and finance ratios are common indicators for measuring mosque cooperatives' financial performance. These indicators include profitability ratios, liquidity ratios, efficiency ratios, and leverage ratios.

\subsubsection{Non-Financial Performance}

On the other hand, non-financial cooperative performance is also essential. According to SKM (2009), cooperatives' non-financial indicators consist of good governance, members' satisfaction, quality products or services, and social responsibilities. However, according to Kaur (2006), there is no simple accepted formula to measure cooperatives' non-financial performance dimension.

In the same vein, mosque cooperative needs to meet its non-financial performance indicators. It has obligations towards members, their families, mosque institutions, and society at large. Moreover, the Jabatan Kemajuan Islam Malaysia (JAKIM) has also formulated the mosque institution performance framework, which emphasis on four aspects, namely management, activism, infrastructure, and surrounding (cleanliness, beautifulness, and safety). This framework is also known as the Standard Penarafan Masjid Malaysia (SPMM) (JAKIM, 2009). Hence, mosque cooperative could engage SPMM framework to indicate its non-financial performance.

From the preceding arguments, like another type of cooperative, mosque cooperative has to address economic and social expectation. It competes with other business entities economically and uses the economic returns to support member socially. Thus, mosque cooperative must perform financially to meet its non-financial obligations. Hence, it leads to the formulation of Hypothesis 1, which states:

\section{$H_{1}$ : Mosque cooperatives financial performance positively influences mosque cooperatives non-financial performance}

\subsection{Determinants of Mosque Cooperatives' Performance}

The next sub-section assessed and evaluated past studies concerning determinants of cooperatives' performance. These determinants encompassed board members' characteristics, members' support, and internal supervision and monitoring.

\subsubsection{Board Members' Characteristics}

Board members' attributes are one of the predictors of cooperative's performance. Previous assessments by Bruynis, Goldsmith, Hahn, \& Taylor (2001), Carr, Kariyawasam, \& Casil (2008), and Noordin, Sushila, Said, Juhan, \& Mohd Hanif (2011) reflected a positive association between board members' characteristics and cooperatives performance. For example, Bruynis et al. (2001); Carr et al. (2008); Noordin et al. (2011) found support for board members' characteristics such as education level, competencies, previous working experiences, and cooperative involvement track of the record. Additionally, Noordin et al. (2011) found support for attributes such as age, working experience, the number of years in the cooperative movement, and leadership stability. These studies found support on the essential of an individual with appropriate competencies, knowledge, and 
experience to occupy cooperative's boardroom for a better strategic management, as well as dealing with the turbulence of corporate environment swiftly.

Further investigation also found support for the influence of board members' characteristics and cooperatives' performance. Othman, Kari, Jani, \& Hamdan (2012) evidenced the essential of board members' expertise and competencies in driving cooperatives performance. Besides, Ernst \& Young (2012) also emphasised the importance of board members' skills, competencies, and length of service as determinants of cooperatives performance. In addition, Othman, Mohamad, \& Abdullah (2013) also highlighted the essential of networking skill among board members in driving cooperative performance. In supporting this, board members with extensive previous working experience and long involvement in cooperative sector allows better communication with regulators, stakeholders, and potential business partners; thus, offering advantages in driving cooperative's performance.

Hence, from the preceding arguments, it leads to the formulation of Hypothesis 2, which states:

\section{$\mathrm{H}_{2}$ : Board members' characteristics positively influences mosque cooperatives financial performance}

\subsubsection{Internal Supervision and Monitoring}

The performance of cooperatives also is subject to effective internal control (Othman et al., 2013; Zaridis \& Mousiolis, 2014). In supporting the point, Huang (2010) evidenced that effective internal supervision and monitoring improves the performance of entities that have economic and social goals, which include cooperatives. Additionally, proper internal supervision is a pre-requisite to balance the trade-offs between cooperatives' economic and social agenda (Franken \& Cook, 2013).

In the analysis, Noordin et al. (2011) established a direct relationship between proper internal governance and cooperatives' performance. The study concluded that a performing cooperative maintains systematic accounting records and disclosure; however, more initiatives are required to enhance internal control and risk management system, especially in monitoring investment and spending programmes. Besides, Huang et al. (2015) listed weak internal monitoring, ineffective internal control, and poor risk management as potential obstacles in driving cooperatives' performance. In addition, Kontogeorgos, Chatzitheodoridis, \& Theodossiou (2014) reminded cooperators that past board and management failure to provide effective monitoring could hinder additional investment, trust, and support among members in future. Additionally, Shariff, Abidin, \& Manaf (2016) indicated that most of the cooperative board members rated the essentiality of effective internal supervision and monitoring highly in driving cooperatives' performance.

Hence, from the prior arguments, it leads to the formulation of Hypothesis 3, which states:

\section{$H_{3}$ : Internal supervision and monitoring positively influence mosque cooperatives financial performance}

\subsubsection{Members Support}

Kaur (2006) argued that members of cooperative wear two hats - as an owner and as a customer. Being an owner, members provide monetary and non-monetary resources which are essential for cooperative's growth and development. Additionally, being a customer, members consume cooperative's products or services, which ensure sustainability income and economic return. Besides, Sushila et al. (2009) emphasised members support as a determinant of co-operatives' performance, in particular members' participation and education. In addition, Sarif \& Ismail (2010) found that members allocated more than fifty percent of their time to attend meeting and seminar relating to cooperatives well-being. Attending cooperative annual general meeting indicates participation level among members. Members' presences provide check and balance towards board members and managers of cooperative (Aini, Hafizah, \& Zuraini, 2012). Annual general meeting platform also allows members to provide feedback and ideas for cooperative improvement. Additionally, more educated members offer potential talents and human capital capability for cooperative's expansion. In fact, Bidin (2007) highlighted the essential of knowledge among members, and exchange knowledge system in driving cooperatives' performance.

Furthermore, Harun \& Mahmood (2012) argued that members' cohesiveness and loyalty play essential roles in supporting cooperatives' performance. Members' continuous support towards cooperative's activities ensures the fulfillment of its going concern postulate and achievement of objectives. In addition, Othman et al. (2012) found empirical support for the relationship between members' participation and cooperative's share increment. It indicated that the most committed members allow cooperative to gather more capital or resources for future expansion.

Studies by Amini \& Ramezani (2008); Bruynis et al. (2001); Huang et al. (2015) and Noordin et al. (2011) also 
found empirical support on the positive relationship between members' involvement and cooperative's performance. For instance, Huang et al. (2015) indicated a positive relationship between attendance of members at the annual general meeting and cooperative's financial performance. Hence, from the preceding arguments, it leads to the formulation of Hypothesis 4, which states:

\section{$H_{4}$ : Members support positively influences mosque cooperatives financial performance}

\section{Research Method}

\subsection{Research Framework}

In order to evaluate factors determining the performance of co-operatives in Malaysia, Sushila et al. (2009) has proposed a model. It encompassed structural dimension, managerial dimension, and membership dimension in predicting the financial and non-financial performance of a co-operative. Structural dimension encompassed elements of size, firm entrepreneurial culture, service provision, the cost of operation, and diversification of activities. Managerial dimension consisted of a long-term plan, competency, management training, and full time managers. The membership dimension covered member participation and member education. The framework is nevertheless heavily focused on conventional co-operatives' financial performance viz. profitability, liquidity, efficiency, and leverage ratios. Besides, there was a lack of emperical tests on cooperatives' non-financial performance indicators such as member satisfaction, longevity, and membership growth. Moreover, the model was yet to be validated.

Hence, the framework of this study incorporates the non-financial performance in the critical success factors model for mosque co-operatives. The DKN 2 indeed has also underlined that the contribution of mosque co-operatives towards mosque institutions' activism, social responsibility engagement, and good governance. The framework proposes that board members' characteristics, internal supervision and monitoring, and members' support influence financial performance of mosque co-operatives. Additionally, the framework proposes that financial performance influences the non-financial performance of mosque co-operatives. Figure 1, illustrates the proposed framework of antecedents of mosque cooperatives performance.

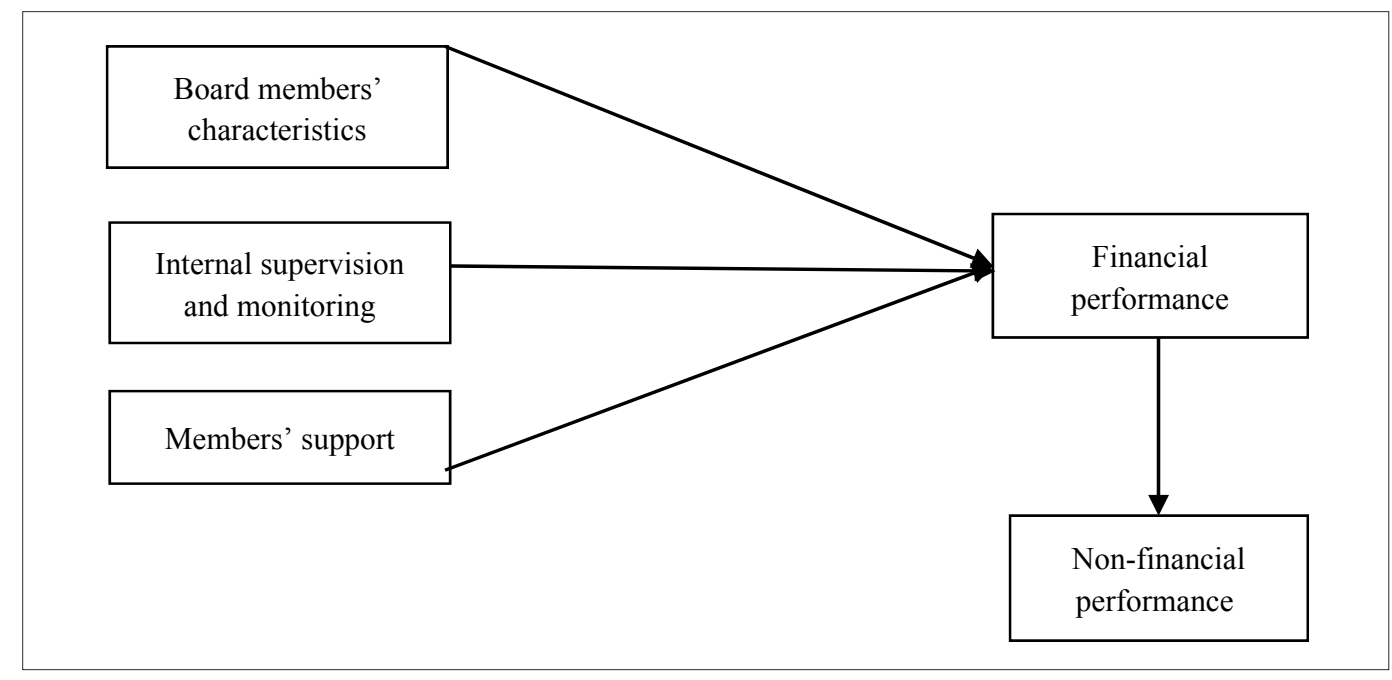

Figure 1. Proposed Framework of Antecedents of Mosque Cooperatives Performance

From the framework, dependent variables were financial performance and non-financial performance of mosque cooperatives. There were three independent variables namely board members' characteristic, internal supervision and monitoring, and members' support. The following Table 1 depicts the description and measurement of variables in this study.

Table 1. Description and Measurement of Variables

\begin{tabular}{lclc}
\hline Variable & Definition & Measurement method & Source \\
\hline Dependent variable & & & \\
\hline Financial performance & $\begin{array}{c}\text { Financial } \\
\text { performance of } \\
\text { mosque co-operatives }\end{array}$ & $\begin{array}{c}\text { Gross profit margin } \\
\text { Net profit margin }\end{array}$ & SKM09) \\
\hline
\end{tabular}




\begin{tabular}{|c|c|c|c|}
\hline & & $\begin{array}{l}\text { Return on assets } \\
\text { Return on members' fund } \\
\text { Current ratio } \\
\text { Gearing ratio } \\
\text { Net tangible asset }\end{array}$ & \\
\hline \multirow[t]{6}{*}{$\begin{array}{l}\text { Non-financial } \\
\text { performance }\end{array}$} & \multirow[t]{6}{*}{$\begin{array}{c}\text { Non-financial } \\
\text { performance of } \\
\text { mosque co-operatives }\end{array}$} & $\begin{array}{lcr}\begin{array}{l}\text { Perceived } \\
\text { towards }\end{array} & \text { members' } & \text { satisfaction } \\
\text { services } & & \\
\text { co-operatives' }\end{array}$ & SKM, (2009) \\
\hline & & Co-operative governance & \\
\hline & & Social responsibility achievement & \\
\hline & & Supporting mosque activism & \\
\hline & & Membership growth & Sushila et al. (2009) \\
\hline & & $\begin{array}{l}\text { Mosque activism, infrastructure, } \\
\text { management, and surrounding }\end{array}$ & JAKIM, (2009) \\
\hline \multicolumn{4}{|l|}{ Independent variables } \\
\hline $\begin{array}{l}\text { Board members } \\
\text { characteristics }\end{array}$ & $\begin{array}{l}\text { To indicate board } \\
\text { members' attributes }\end{array}$ & $\begin{array}{l}\text { Board members' education, working } \\
\text { experience, co-operative involvement } \\
\text { experience and training attendance }\end{array}$ & Sushila et al. (2009) \\
\hline $\begin{array}{l}\text { Internal supervision and } \\
\text { monitoring }\end{array}$ & $\begin{array}{l}\text { To measure mosque } \\
\text { co-operatives' } \\
\text { internal supervision } \\
\text { and control } \\
\text { mechanism }\end{array}$ & $\begin{array}{l}\text { Existence of internal control policies } \\
\text { Existence of spending and investing } \\
\text { policies } \\
\text { Existence of accurate financial records } \\
\text { policies }\end{array}$ & Noordin et al. (2011) \\
\hline Members' support & $\begin{array}{l}\text { To measure members' } \\
\text { level of support }\end{array}$ & $\begin{array}{l}\text { Members support regarding attending } \\
\text { co-operative's annual meeting, buying } \\
\text { co-operative's services or products, } \\
\text { increasing contribution to members' } \\
\text { fund and awareness on members' } \\
\text { rights and responsibilities }\end{array}$ & Sushila et al. (2009) \\
\hline
\end{tabular}

\subsection{Population and Sample of Study}

This study targeted respondents were mosque co-operatives' board of directors' members. The purposive sampling method was deployed to select the respondents. These respondents were considered appropriate due to their sound knowledge of cooperatives and ability to feedback the survey about issues surrounding cooperatives. The questionnaires were distributed to those respondents who attended the business development workshop organized by ANGKASA at Port Dickson from 18 to $19^{\text {th }}$ May 2016. The participants were mosque co-operatives' board of directors members from the state of Negeri Sembilan, Selangor, and Kuala Lumpur. The purposive sampling method was also adopted in previous studies by Sushila et al. (2009; 2010).

The business development workshop was part of continuous professional enhancement initiative by ANGKASA to equip mosque co-operators with the latest knowledge, information, and skill in moving forward their respective mosque co-operatives. In total, 51 questionnaires were distributed to participants of business development workshop in Port Dickson.

\section{Analysis, Findings, and Discussion}

The proposed research framework was tested using PLS 2.0 programme to measure the strength of relationships. Convergent and discriminant validity were also used to test construct validity and reliability. PLS is used because it is considering as a powerful method of analysis due to the minimal demands on measurement scales, sample size, and residual distributions (Wold, 1985). Compared with the well known factor-based covariance fitting approach for latent structural modeling, the component based PLS avoids two serious problems which are inadmissible solutions and factor indeterminacy (Fornell \& Bookstein, 1981). The utility of the PLS method has been documented elsewhere (Falk \& Miller, 1992) as possibly more appropriate for a large data sets to be used among researchers.

\subsection{Convergence Validity}

This study employed convergent validity and discriminant validity in ensuring the validity and reliability of the measurement model. Item reliability, composite reliability, and the average variance extracted (AVE) evaluated 
the convergent validity of the items for each construct (Fornell \& Bookstein, 1981). In this study, the confirmatory factor analysis (CFA) results demonstrated that the loadings of all items were significant $(\mathrm{p}<.01)$ and were greater than .5 , indicating good item reliability (Hair et al., 2010). Table 2 demonstrates satisfactory convergent and discriminant validity of the measures. The AVE for all constructs is more than .50; and the composite reliability of each construct is above the threshold of 7 (Hair et al., 2010). Thus, the above evidence shows satisfactory convergence validity of the constructs examined in the study.

\subsection{Discriminant Validity}

Discriminant validity measures the extent to which constructs differ from one another. It is assessed by comparing the square root of a given construct's AVE with the correlations between that construct and all others (Hair et al., 2010). Table 2 shows that the estimates for all constructs are more strongly correlated with their specific measures than with any of the other constructs. Diagonal elements are the square root of the variance shared between the constructs and their measurement (AVE). Off-diagonal elements are the correlations among constructs. Diagonal elements should be larger than off-diagonal elements in order to obtain the discriminant validity. The findings revealed a high level of discriminant validity. Having achieved convergent validity and discriminant validity, the constructs in the proposed model are deemed adequate.

Table 2. Convergent and Discriminant Validity Coefficients

\begin{tabular}{llcccccc}
\hline \multicolumn{1}{c}{ Construct } & AVE & CR & $\mathbf{1}$ & $\mathbf{2}$ & $\mathbf{3}$ & $\mathbf{4}$ & $\mathbf{5}$ \\
\hline 1. Board members & 0.80 & 0.85 & $\mathbf{0 . 8 9}$ & & & & \\
2. Internal control and supervision & 0.70 & 0.92 & 0.70 & $\mathbf{0 . 8 4}$ & & & \\
3. Members' support & 0.79 & 0.94 & 0.73 & 0.69 & $\mathbf{0 . 8 9}$ & \\
4. Financial & 0.86 & 0.95 & 0.84 & 0.65 & 0.74 & $\mathbf{0 . 9 3}$ & \\
5. Non-Financial & 0.66 & 0.97 & 0.71 & 0.53 & 0.67 & 0.71 & $\mathbf{0 . 8 1}$ \\
\hline
\end{tabular}

\subsection{Respondents' Profile}

From 51 distributed survey forms, 41 were completed and returned. It was an $80.39 \%$ response rate. After further checking, all 41 survey forms were found fit for further analysis. Regarding age, the respondents' average is 59.09. Table 3 depicts the summary of respondents' profile.

Table 3. Respondents' Profile

\begin{tabular}{|c|c|c|c|}
\hline Categories & Details & Frequency & Percentage $\%$ \\
\hline \multirow{4}{*}{ State } & Negeri Sembilan & 31 & 75.6 \\
\hline & Selangor & 9 & 22.0 \\
\hline & Kuala Lumpur & 1 & 2.4 \\
\hline & Chairman of Board & 6 & 14.6 \\
\hline \multirow{4}{*}{ Position } & Secretary & 11 & 26.8 \\
\hline & Treasurer & 6 & 14.6 \\
\hline & Board Member & 13 & 31.7 \\
\hline & Member & 4 & 9.8 \\
\hline \multirow{6}{*}{ Education } & First degree & 5 & 12.2 \\
\hline & Professional & 2 & 4.9 \\
\hline & Diploma & 11 & 26.8 \\
\hline & ${ }^{\wedge} \mathrm{STPM}$ & 6 & 14.6 \\
\hline & ${ }^{\wedge} \mathrm{SPM}$ & 11 & 26.8 \\
\hline & $\wedge \wedge \wedge \mathrm{PMR}$ & 6 & 14.6 \\
\hline \multirow{3}{*}{ Co-operatives experience } & Less than five years & 32 & 78.0 \\
\hline & 6 to 10 years & 4 & 9.8 \\
\hline & 11 to 15 years & 3 & 7.6 \\
\hline \multirow{3}{*}{ Gender } & More than 25 years & 2 & 4.9 \\
\hline & Male & 37 & 90.2 \\
\hline & Female & 4 & 9.8 \\
\hline \multirow{3}{*}{ Working experience } & Public service & 20 & 48.8 \\
\hline & Private & 10 & 24.4 \\
\hline & Self-business & 9 & 22.0 \\
\hline
\end{tabular}


Note: ^Sijil Tinggi Pelajaran Malaysia (Higher School Certificate); $\wedge^{\wedge}$ Sijil Pelajaran Malaysia (Malaysian Certificate of Education); ${ }^{\wedge \wedge}$ Penilaian Menengah Rendah (Lower Certificate of Education

\subsection{Descriptive Analysis}

Further assessments were carried out to determine the mean of each determinant. The highest mean with the value of 5.54, indicating that the main determinant towards mosque co-operatives' financial and non-financial performance is board members' characteristics. The next variable is members' support with the mean score of 5.34. The lowest mean with the value of 5.22 is for internal supervision and monitoring. In addition, mean for financial performance is 5.03; and it is slightly lower than a mean for non-financial performance at 5.18. This score is consistent with previous arguments by Hind (1999); Hussain, Gunasekaran, \& Islam (2002) and Mayo (2011) on the greater importance of non-financial indicators against financial indicators among cooperatives. Table 4 depicts the mean value of each determinant of mosque co-operatives' performance.

Table 4. Mean Score for Determinants of Mosque Co-operatives' Performance

\begin{tabular}{lc}
\hline \multicolumn{1}{c}{ Determinants } & Mean \\
\hline Board members' characteristics & 5.54 \\
Internal control and supervision & 5.22 \\
Members' support & 5.34 \\
Financial performance & 5.03 \\
Non-financial performance & 5.18 \\
\hline
\end{tabular}

\subsection{Model and Hypothesis Testing}

After checking validity and reliability requirements, the structural model analysis was carried out. The structural model estimated path coefficients of interdependence relationship between independent and dependent variables in the model under study. Figure 2 illustrates the proposed initial model of antecedents of mosque cooperatives' performance

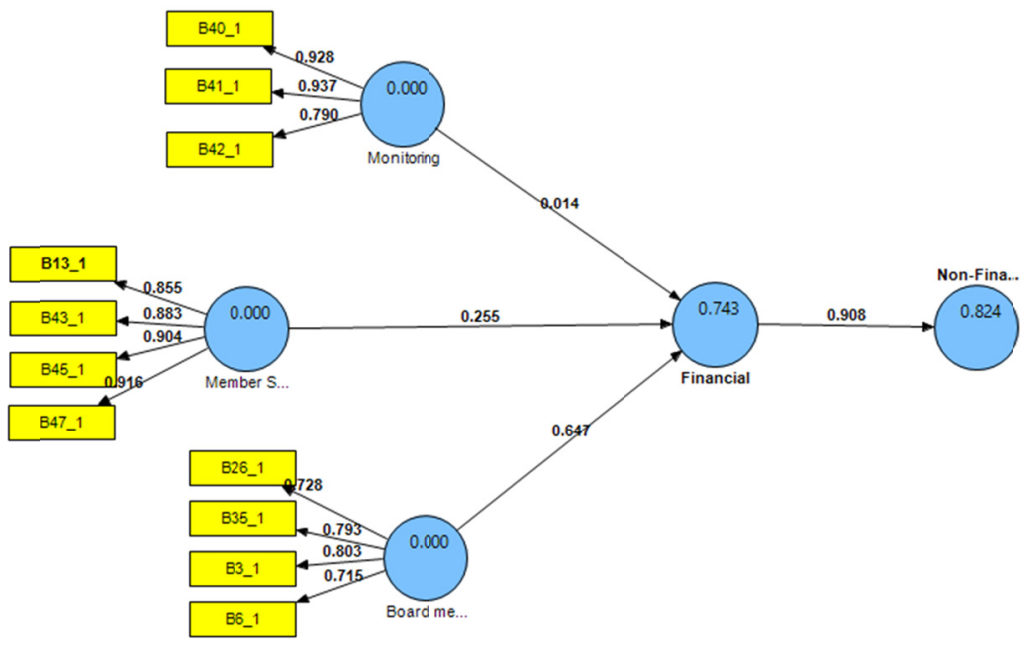

Figure 2. Initial model of antecedents of mosque cooperatives performance

The model test showed that board members' characteristics, members' support, and internal supervision and monitoring positively influenced financial performance of mosque cooperatives. Hence, the findings found support for Hypothesis 2, 3, and 4. Overall, these three determinants explained $74.3 \%$ of mosque cooperatives' financial performance, where $R^{2}=0.743$. The model also indicated that financial performance explained $82.4 \%$ of mosque cooperatives' non-financial performance where $\mathrm{R}^{2}=0.824$. Besides, financial performance positively influenced the non-financial performance of mosque cooperatives; hence, the study found support for Hypothesis 1.

The findings corroborated previous evaluation by Bruynis et al. (2001); Carr et al. (2008); Huang et al. (2015); Noordin et al. (2011); and Sushila et al. (2010) where board members' characteristics positively influenced cooperatives' financial performance. Furthermore, the finding was also consistent with Noordin et al. (2011) and 
Othman, Choo, Zazale, \& Aris (2016) discovery where internal supervision and monitoring positively influenced cooperatives' financial performance. In addition, members' support was found to influence financial performance positively. The finding is consistent with Aini et al. (2012); Amini \& Ramezani (2008); Bruynis et al. (2001); Harun \& Mahmood (2012); Huang et al. (2015); Noordin et al. (2011); Othman et al. (2012) and Sushila et al. (2009).

\section{Conclusion}

\subsection{Achievement of Objective}

This study has achieved the underlined objectives by presenting the predictors of financial and non-financial performance from the perspective of mosque co-operators. There are three identified determinants of mosque cooperatives' performance viz. board characteristics, internal supervision and monitoring, and members' support.

\subsection{Implications of Study}

The study showed that members' support, board members' characteristics, and internal supervision and monitoring primarily influenced mosque cooperative's financial performance, and subsequently financial performance influenced its on-financial performance. Such findings resulted in several implications for consideration of policy makers, regulators, and mosque co-operators.

As a unique business entity, the cooperative is established by members, and the intention is to provide services and render assistance to members in need. The similar principal applies in the context of mosque cooperatives. To perform mosque cooperatives, need strong and undivided support from members. In order to strengthen members' trust, mosque cooperatives' board members and management teams must prove their abilities and competencies to meet members' social expectation. Besides, handsome dividend payout, members also expect assistance regarding enhancing their social capital like skills enhancement, education opportunities, and socioeconomic potential. In addition, board members and management teams must avoid the mistake in administering and directing mosque cooperatives, since such failure may erode members' confidence and trust to support programmes, activities, and initiatives in future.

Secondly, the board members' characteristics have given greater importance on skills, competencies, and expertise as ingredients to drive cooperative performance. Hence, a more systematic and comprehensive training for mosque cooperatives' board members is needed. These training must be an emphasis on a specific capacity that needs to be enhanced, rather a general type of training. Among specific skills needed by mosque cooperatives' board members are networking skills, law and legal skills, and digital economic skills. The requirement for extensive skill based training for cooperatives' board members is also propagated by Manap \& Tehrani (2014).

More importantly, this study has contributed to theoretical and empirical literature in a unique way. Despite the prevalent acceptance that non-financial measures such as member satisfaction improve organisation performance, prior empirical studies provide no support for the claim that these measures are leading indicators of performance. This study provides empirical evidence on the association between non-financial measures and financial performance, and thus validates the assumption maintained in theoretical studies. It supplements the results of earlier studies in the area of accounting and finances that member satisfaction measures are lead indicators of organisation performance. The unique feature of this study is that it uses cross-sectional data and a rich context of institutional details to study the causal relationships between non-financial measures and financial performance. Overall, the study provides useful insights for cooperatives to integrate nonfinancial measures into the design of performance measurement and critical success factors model.

\subsection{Limitation of Study}

There are several limitations in this study. First, this study is limited to mosque co-operatives in three states namely - Selangor, Negeri Sembilan, and Kuala Lumpur. Thus, generalisation should be interpreted with cautious. Next, this study is at the exploratory stage; therefore, the findings should be treated carefully. The absence of a carefully designed control group necessitates caution in the interpretation of the results. The study relies on alternate control measures in the form of competitor data, but for the non-financial measures, it is not possible to obtain comparable measures from the competitors. The construct validity of member satisfaction measures can be questioned. To that extent, this study has attempted to examine alternate measures of member satisfaction

\subsection{Recommendation for Future Studies}

In future, efforts can be carried out to include possible mediating and moderating predictors in the proposed 
model. One of the possible moderators is categories of mosque cooperatives. First, mosque cooperative can be classified into its location such as rural area, and urban area. Secondly, according to the common classification of SKM, like other conventional cooperatives, mosque cooperatives can be classified into new, potential, and highly performing cooperatives. The incorporation of mediating and moderating predictors in the model shall provide a deeper understanding of the dynamic influence of antecedents of mosque cooperative performance; hence assisting players in the industry to devise a more comprehensive action plan to boost financial performance and non-financial performance.

Besides, the sample of the study also can be expanded by incorporating mosque cooperatives in other states. Even though PLS technique is considered powerful and appropriate to analyse small sample; enlarging the possible respondents contribute to stronger generalisation. Also, it allows comparative analysis on the performance of mosque cooperatives across 13 states in the federation of Malaysia. Each state is expected to have its unique settings and challenges concerning mosque cooperative, since the control of Islamic institution is under the authority and sovereignty of each state, as stipulated by the Ninth Schedule of the Federal Constitution. Also, the comparative analysis may be expanded to obtain a more holistic understanding of mosque co-operatives' performance in other jurisdiction such as Cambodia, Indonesia, and Thailand.

\section{References}

Aini, Y. M., Hafizah, H. A. K., \& Zuraini, Y. (2012). Factors Affecting Cooperatives' Performance in Relation to Strategic Planning and Members' Participation. Procedia - Social and Behavioral Sciences, 65, 100-105. http://doi.org/10.1016/j.sbspro.2012.11.098

Amini, A. M., \& Ramezani, M. (2008). Investigating the Success Factors of Poultry Growers' Cooperatives in Iran's Western Provinces. World Applied Sciences Journal, 5(1), 81-87.

Bidin, Y. H. (2007). Positioning Knowledge Management As Key Success Factor in the Growth of Cooperatives in Malaysia. Asian Academy of Management Journal, 12(1), 69-82.

Bruynis, C. L., Goldsmith, P., Hahn, D. E., \& Taylor, W. J. (2001). Key Success Factors For Emerging Agricultural Marketing Cooperatives. Journal of Cooperation, 16(January), 14-24.

Carr, A., Kariyawasam, A., \& Casil, M. (2008). A Study of the Organizational Characteristics of Successful Cooperatives by A Study of the Organizational Characteristics of Successful Cooperatives. Organization Development Journal, 26(1), 79-88.

Chesnick, D. (2005). Measuring top 100 co-op performance. Rural Cooperatives, 72(2), 28-29. Retrieved from http://connection.ebscohost.com/c/articles/16948164/measuring-top-100-co-op-performance

Ernst \& Young. (2012). Enlightened co-operative governance, 1-16.

Falk, R. F., \& Miller, N. B. (1992). A Primer for Soft Modeling. University of Akron Press.

Fornell, C., \& Bookstein, F. L. (1981). Evaluating Structural Equation Models with Unobservable Variables and Measurement Error. Journal of Marketing Research, 18(1), 39. http://doi.org/10.2307/3151312

Franken, J. R. . V. ., \& Cook, M. L. (2013). Impact of Board Structure and Process on Cooperative Performance. Agricultural \& Applied Economics.

Hair, J. F., Black, W. C., Babin, B. J., \& Anderson, R. E. (2010). Multivariate Data Analysis (7th ed.). Upper Saddle River, New Jersey: Prentice Hall.

Harun, M. Z. M. bin, \& Mahmood, R. bin. (2012). The Relationship between Group Cohesiveness and Performance: An Empirical Study of Cooperatives Movement in Malaysia. Journal of Cooperative Studies, 1(1), 15-20. http://doi.org/10.11634/216826311403110

Hind, A. M. (1999). Life Cycle and Goals Abigail M. Hind. Journal of Agricultural Economic, 50(3), 536-548.

Huang, C.-J. (2010). Corporate governance, corporate social responsibility and corporate performance. Journal of Management and Organization, 16(5), 641-655. http://doi.org/10.5172/jmo.2010.16.5.641

Huang, C. C., Zazale, S., Othman, R., Aris, N. A., Maznah, S., \& Ariff, M. (2015). Influence of cooperative members' participation and gender on performance. Journal of Southeast Asian Research, 2015, 1-9. http://doi.org/10.5171/2015.610199

Hussain, M., Gunasekaran, A., \& Islam, M. M. (2002). Implications of non-financial performance measures in Finnish banks. Managerial Auditing Journal, 17(8), 452-463. http://doi.org/10.1108/02686900210444798

Jabatan Kemajuan Islam Malaysia (JAKIM). (2009). Standard Penarafan Masjid Malaysia. Retrieved January 6, 
2017, from http://jkim.islam.gov.my/standard-penarafan-masjid-malaysia

Kaur, I. (2006). Performance measurement: An evaluation of cooperative performance in Malaysia. Journal of Cooperative, 2(1), 28-42. Retrieved from http://www.mkm.edu.my/index.php/en/penerbitan/jurnal

Kontogeorgos, A., Chatzitheodoridis, F., \& Theodossiou, G. (2014). Willingness To Invest In Agricultural Cooperatives : Evidence From Greece. Journal of Rural Cooperation, 42(2), 121-137.

Manap, N. A., \& Tehrani, P. M. (2014). The Contribution of Cooperative Law to Economic Development in Malaysia. Asian Social Science, 10(15), 283-291. http://doi.org/10.5539/ass.v10n15p283

Mayo, E. (2011). Co - operative performance. Sustainability Accounting, Management and Policy Journal, 2(1), 158-164. http://doi.org/10.1108/20408021111162182

Noordin, N., Sushila, D. R., Said, M. S. A., Juhan, R., \& Mohd Hanif, F. (2011). Attributes and Perceived: Success Factors of Performing Cooperatives in Malaysia. Monograf Penyelidikan. Maktab Koperasi Malaysia. Retrieved from http://www.mkm.edu.my/index.php/my/penerbitan/monograf-penyelidikan/book/ 146-attributes-and-perceived-success-factors-of-performing-cooperatives-in-malaysia/7-monograf-penyelid ikan

Othman, A., Kari, F., Jani, R., \& Hamdan, R. (2012). Factors influencing cooperative membership and share increment : an application of the logistic regression analysis in the Malaysian cooperatives. World Review of Business Research, 2(5), 24-35.

Othman, I. W., Mohamad, M., \& Abdullah, A. (2013). Cooperative Movements in Malaysia: The Issue of Governance. International Journal of Social, Behavioral, Educational, Economic, Business and Industrial Engineering, 7(6), 398-402. Retrieved from http://www.waset.org/publications/8324

Othman, R., Choo, H. C., Zazale, S., \& Aris, N. A. (2016). Human-Capital based Governance Structure, Success Factors and Barriers to Effective Governance: Co-operatives in Malaysia. Environment-Behaviour Proceedings Journal, 1(1), 394-400.

Sarif, S. M., \& Ismail, Y. (2010). Managerial roles and the training of Malaysian co-operatives' managers. Malaysian Journal of Co-Operative Studies, 6(2010), 49-63.

Shariff, N. M., Abidin, A. Z., \& Manaf, A. (2016). Investigating Board of Directors ' Perceptions on Corporate Governance Practice in Cooperatives. Malaysian Journal of Co-Operative Studies, 3(1), 265-289.

Suruhanjaya Koperasi Malaysia (SKM). (2009). Indeks 100 Koperasi Terbaik Malaysia 2009, Kuala Lumpur. Retrieved from http://www.skm.gov.my/index.php/my/component/flippingbook/book/12?layout=edit

Suruhanjaya Koperasi Malaysia (SKM). (2011). Dasar Koperasi Negara 2011-2020. Retrieved from http://www.skm.gov.my/index.php/my/mengenai-skm/gerakan-koperasi/dasar-koperasi-negara-2011-2020

Suruhanjaya Koperasi Malaysia (SKM). (2015). Laporan Perangkaan Am Koperasi Malaysia - Perangkaan Am Koperasi Mengikut Kumpulan Sasar pada 31 Disember 2015. Retrieved from http://www.data.gov.my/data/ dataset/laporan-perangkaan-am-koperasi-malaysia-26/resource/930ef967-55f4-4d61-9203-7304f2de7df7

Sushila, D. R., Noordin, N., Said, M. S. A., Juhan, R., \& Mohd Hanif, F. (2009). Factors Influencing The Performance of Cooperatives In Malaysia: A Tentative Framework. Malaysian Journal of Cooperative Management, 5(1), 43-61. Retrieved from http://www.mkm.edu.my/index.php/en/publication/journal

Sushila, D. R., Noordin, N., Said, M. S. A., Juhan, R., \& Mohd Hanif, F. (2010). Success Factors of Cooperatives In Malaysia: An Exploratory Investigation. Malaysian Journal of Cooperative Management, 5(1), 1-24. Retrieved from http://www.mkm.edu.my/index.php/en/publication/journal

Wold, H. (1985). Partial least squares. Encyclopedia of Statistical Sciences, 6(2), 581-591. http://doi.org/10.1002/0471667196

Zaridis, A. D., \& Mousiolis, D. T. (2014). ScienceDirect Entrepreneurship and SME's Organizational Structure. Elements of a Successful Business. Procedia -Social and Behavioral Sciences, 148, 463-467. http://doi.org/10.1016/j.sbspro.2014.07.066

\section{Copyrights}

Copyright for this article is retained by the author(s), with first publication rights granted to the journal.

This is an open-access article distributed under the terms and conditions of the Creative Commons Attribution license (http://creativecommons.org/licenses/by/4.0/). 